\title{
Ecological Theory Origin from Natural to Social Science or Vice Versa? A Brief Conceptual History for Social Work
}

\author{
Karen Smith Rotabi
}

\begin{abstract}
The origin of holistic social work and ecological theory was investigated. Emphasis was placed on Howard W. Odum, founding dean of the University of North Carolina School of Public Welfare, and subsequent scholarship by his sons, collaborators on the first American ecology text. Eugene and Howard Thomas Odum, internationally recognized ecological scholars, identified holism as a universal concept originating in social sciences, crediting their father's earlier sociological work, which later bridged to ecosystems ecology. A historical review of the influential sociologists, social workers, and ecologists is presented to build the case for ecological theory transfer across the three disciplines, beginning with sociology. Critique of the current use of the ecological perspective is discussed, specifically social work's tendency to target social systems and behavior while largely ignoring the natural environment.
\end{abstract}

Keywords: Ecology, ecosystem, regionalism, science, history, Odum

\section{INTRODUCTION}

Social work theory is integrative by nature, pulling from a variety of disciplines (Payne, 1997; Robbins, Chatterjee, \& Canda, 1998). We typically think of sociology and psychology as two primary theory sources. However, other disciplines have also had an important influence on social work theory, especially natural science ecology. Because natural science ecology theory predates the formal use of the term ecology in social work (Germain, 1973; Golley, 1993; Tansley, 1935; Odum, 1953), a one-way transfer of theory from natural science to social work may be assumed. However, a longer-term historical view indicates otherwise-with social sciences directly influencing the development of natural science ecology in North America.

The foundation for the assertion that social sciences have informed theory development in natural science ecology is anchored in the work of two generations of theorists from the Odum family (Craige, 2001; Hagen, 1992; Kirby, 1991; Rotabi, 2004). The story begins with Howard W. Odum (1884-1954), a sociologist

Karen Smith Rotabi, Ph.D., LMSW, MPH is assistant professor of Social Work, School of Social Work, Virginia Commonwealth University, Richmond, VA 23284-2027.

Copyright $^{\oplus} 2007$ Advances in Social Work Vol. 8 No. 1 (Spring 2007) 113-129. Indiana University School of Social Work. 
and founding dean of the University of North Carolina (UNC) School of Public Welfare (Brazil, 1988). In addition to his innovations in social work education and important and progressive work in social reform in the South (Brazil, 1988; Odum, 1923a,b,c,d, 1926, 1932, 1934, 1936, 1939, 1945, 1947a, 1947b, 1997), H.W. Odum founded the science of regionalism (Brazil, 1988; Kirby, 1991; Odum, 1977; Odum, 1936, Odum \& Moore, 1938) which is the forerunner of the current discipline of landscape ecology (Odum, 2004).

The next generation of scholars in the Odum family, his sons Eugene P. Odum (1913-2002) and Howard T. Odum (1924-2002), continued their father's theory building in natural systems ecology (Rotabi, 2004). Just as their father before them, both E.P. and H.T. Odum have written broadly on the subject of ecology, consistently bringing the reader back to questions about human problems and solutions (Craige, 2001; Odum, 1977, 1983, 1993, 1997, 2004; Odum, 1971, 1983, 1994; Odum, 2001). Between the two generations of scholars, approximately 75 books have been published and countless manuscripts. H.W. Odum's social sciences theory development was then transferred to his sons, who consistently referred to their father's work, especially regionalism, as an important influence to their own contributions in natural science ecology (Craige, 2001; Hagen, 1995; Kirby, 1991; Odum, 1977, 2004; Odum, 1971).

The family's contribution to ecological theory development has been extraordinary, and this foundation has had a significant impact on science and a number of disciplines, including social work. With the emergence of ecology as a unique science in North America, social work theorists, including Carel Germain, Alex Gitterman, and others, have built a substantial body of theory that is typically called the "ecological perspective" or "person-in-environment" (Germain, 1973, 1979a, 1979b; Germain \& Gitterman, 1980, 1995, 1996; Grief \& Lynch, 1983; Karls \& Wandrei, 1994; Meyer, 1983; Siporin, 1980). Today, ecology is a fundamental conceptual framework for Human Behavior in the Social Environment curriculum in social work education (Anderson \& Carter, 1974, 1984, 1990; Germain, 1991; Hutchinson, 1999). However, in social work, the origin of ecology is largely misunderstood, and its application has been limited to social environment rather than more holistically including natural environments. This limitation ultimately ignores the importance of natural science ecology (Rotabi, 2004).

This paper presents a brief history of ecological theory in sociology, ecology, and social work. It is part of a larger body of work that analyzes the legacy of the Odum family in the history of science (Rotabi, 2004). Focus will be the relevant work of both Odum generations and other scholars, which under gird the social work ecological perspective. More recent social work theory development will be presented. Finally, the strengths and weakness of the current use of ecology in social work will be discussed.

\section{Sociology: Howard W. Odum}

Just like Jane Addams (Deegan, 1988), the elder Odum considered himself a sociologist. As such, he took a holistic view of social systems, indicating that "society and nature are inseparable" (Odum, 1947b, p. 83). This perspective is found throughout his work, beginning in his earliest documentation of folk music in the 
South (Odum, 1909), which is recognized to be the earliest publication of African American Blues music (Sanders, 2003). Documenting Blues music and folklore and its emergence from both natural and social environments was the beginning of Odum's research career, and this work remained a passion throughout his life (Sanders, 2003).

H.W. Odum started with folk documentation and expanded into questions about race and race relations. Some of this earliest work is considered, by today's standards, to be racist (Sanders, 2003). However, at the time, Odum was carrying out far more progressive research than his contemporaries. He actually entered African American communities and carried out ethnographic research in the South (Brazil, 1988), setting one of the first studies of its kind into motion. Odum described his reasons for selecting this topic of research as follows:

The studies themselves grew out of the observation that there had been practically no scientific studies of the Negro in the South; that the South itself was amazingly ignorant about the Negro; that practically no one was interested in the subject; and that nevertheless this was the distinctive field of inquiry where knowledge must be had before progress in other respects could be made (1951, p. 154).

This passage not only indicates Odum's interest in the culture and anthropology of African Americans, but it also illustrates his ability to see research as providing guidance for social and policy change.

Odum made some mistakes, and most glaringly, he initially promoted the idea that African Americans were inferior (Brazil, 1988; Sanders, 2003). However, during this early research, he began to question the implication of social environments on human behavior and educational outcomes. In the course of this research, Odum came to some realizations about social environment issues for which he began suggesting change strategies (Brazil, 1988). For example, he noted that textbooks for African American children had illustrations of only Caucasian children who were spared the hardship of childhood labor and possessed such luxuries as toys and pets (Brazil, 1988; Odum, 1910; Sosna, 1977). Odum suggested that African American schoolchildren be given culturally appropriate texts that more adequately represent their reality to encourage learning. While diversity in educational materials is more commonplace today, it was a radical idea at the time. This early prescriptive work marks the beginning of Odum's examination of the impact of social environments on human development and made recommendations for progressive social change. This emphasis on environment- the context for behavior-became an increasingly central characteristic in his subsequent writing (Brazil, 1988; Sosna, 1977). Odum became increasingly tolerant (Sanders, 2003) and was considered to be an important and leading liberal scholar in the South (Sosna, 1977), often taking great personal risks by attacking the Klu Klux Klan, documenting lynchings, and other social dynamics (Odum, 1923, 1931, 1997).

One must judge a man by his behavior to fully understand his value system. In the case of H.W. Odum, he was deeply committed to social reform. His progressive viewpoints were rooted in his graduate training, which took him to the Northeast. Odum earned a Ph.D. in psychology (1909) at Clark University and a Ph.D. in soci- 
ology (1910) at Columbia University. Odum had an opportunity to view the beginning of social work education at Columbia (Feldman \& Kamerman, 2001), and he returned to the South intent on developing a social welfare education program. By 1920, Odum founded the UNC School of Public Welfare, with a vision for a broad curriculum grounded in multiple sciences, including geography, sanitation, and biology (H.W. Odum, 1920). Odum headed the school for over a decade, wrote extensively on the subject of social welfare (Odum 1923c,d, 1926, Odum \& Willard, 1925), and developed important social work training programs (Brazil, 1988). Odum's commitment to the profession was such that, when founding The Journal of Social Forces in 1922, he established a permanent public welfare section reporting the proceedings of charities and corrections conferences, educational opportunities, practice standards, and research (Odum, 1922).

H.W. Odum's integration of natural and social sciences was most obvious in his later work, beginning with Southern Regions of the United States (1938). Historian Morton Sosna discusses this text and Odum's founding the discipline of regionalism, noting that the regionalist's belief that "resource planning could advance the nation's welfare provided the differences between the six regions were taken into account. In [the regionalists'] view, the whole would, and should, be greater than the sum of its parts" (Sosna, 1977, p. 56). H.W. Odum laid out a holistic template for national planning and "development through a fine equilibrium of geographic, cultural, and historical factors" (Odum \& Moore, 1938, p. 39).

From 1920 until the time of his death in 1954, Odum was identified as one of the most progressive Southern scholars, and his publications have led to national recognition for his social reform work in the South (Brazil, 1988; McDonough, 1993; Milligan, 1994; Sosna, 1977). An obituary in The New York Times summarized his contributions as follows: "Odum had laid the groundwork for understanding the facts, customs and history of Southern people. No man in our time then had done more than Odum to help the understanding of the South in the South, and of the South in the nation, too" ("Howard W. Odum, sociologist, dies," 1954).

Odum's approach to social problems was based on a holistic theoretical perspective focusing on and integrating both natural and social environments (Odum, 1934, 1936, 1939, 1945, 1947a,b; Odum \& Moore, 1938). His research focused on both of these systems, emphasizing natural and human resource management from a social policy perspective. His work is one of the earliest examples of the explicit application of ecological theory to social problems. Like his theoretical perspective, Odum's vision for social work education was also holistic, integrating natural and social sciences (Odum, 1920)

\section{Natural Science Ecology: E.P. \& H.T. Odum}

Both of Odum's sons were ecosystem ecologists and carried on their father's holistic legacy by asking large-scale systems questions. Their approach ultimately influenced other academic fields, including social work (Craige, 2001; Hagen, 1992; Kirby, 1991; Odum, 1953, 1977; Smith, 2001). His elder son, E.P. Odum, has been called the father of modern ecology (Craige, 2001) largely because of his book Fundamentals of Ecology (1953), which deals with ecosystem as the central unit of 
study (Craige, 2001; Golley, 1993). This text was the first in America to summarize ecosystem ecology by focusing on holism, and it was the only such text for 10 years (Craige, 2001). Today, it is in its fifth edition and has been translated into more than a dozen languages (Craige, 2001; Hagen, 1992). The younger son, H.T. Odum, collaborated with his brother on Fundamentals of Ecology. He also wrote numerous texts of his own, including Environment, Power, and Society, which he dedicated to his father (Odum, 1971). H.T. Odum discusses the interrelationship of the three systems found in the book title.

The small ecological systems, the large panoramas that include civilized man, and the whole biosphere of the planet earth-all receive only certain amounts of energy. Hence, we approach man and nature by studying limited energy of environmental systems (p. 1).

H.T. Odum goes on to apply the concept of energy flow to society, pointing out man's dependence on and attempts to control natural systems and resources, such as fossil fuels. These sources of energy are then "put back into [man's] environmental system so that his yield of food and critical materials is greater" (Odum, 1971, p. 6). He explores other systems with which man interacts and controls the flow of energy, including religion, politics, and economics.

H.T. Odum later published Systems Ecology: An Introduction (1983), in which he makes a clear link between general systems theory (Bertalanffy, 1968) and ecology, linking systems theory back to social science. Sometimes called the "Odum bible" by his students, Systems Ecology was hailed as "a tour de force of systems thinking focusing on bringing the concepts of systems into general education" (Brown, 2003, p. 1). In a revised edition of this text, entitled Ecological and General Systems (1994), H.T. Odum acknowledges both his father and older brother E.P. Odum among the scholars who were influential in his development of systems theory. More recently, he co-authored with his wife, Elizabeth Odum, $A$ Prosperous Way Down (2001), which is a text that focuses on our current state of resource over-consumption, especially of fossil fuels. His overall work focuses more specifically on energy, and he is recognized as a leader in modeling energy flows across systems including human systems (Hall, 1995).

The scientific achievements of the Odum brothers have been recognized internationally. E.P. Odum was a member of the National Academy of Science and received countless accolades from state, national, and international scientific and other organizations (Craige, 2001). Both brothers were recognized for their contributions to the science of ecology and their collaborative thinking as they shared the Swedish Crafoord Prize, considered ecology's equivalent of the Nobel Prize (Brown, 2003; Craige, 2001; H.T. Odum, 1983). Today, they are recognized as important scholars who developed holistic concepts central to ecology and related natural sciences. Their work typically leads the reader to consider complex issues by relating how larger systems incorporate and interact with the human condition.

From a formal education perspective, both E.P. Odum and H.T. Odum were first influenced by natural science scholars at UNC, where they both received their bachelor's degrees in zoology, then later in their graduate programs, where they received doctoral degrees on this subject-E.P. Odum at the University of Illinois 
and H.T. Odum at Yale University. While at UNC, E.P. and H.T. Odum studied with biologist and family friend Robert Coker. Eugene Odum recalled his tutelage with Coker as being laboratory-based, with his days being spent dissecting frogs and other small animals. This experience impressed upon Eugene the joys of outdoor and naturalistic pursuits, where he could explore the landscape and observe natural phenomena, such as observing birds in their habitats (Craige, 2001). During his graduate work at the University of Illinois, Fredric Clements and Victor Shelford introduced Eugene to the concept of succession (Craige, 2001), a major concept of community ecology. Succession is the way in which communities change over time by going through a series of predictable stages (Carpenter, 1962). For example, a bare field will go through a series of stages, from one with grass, to one with herbs and bushes, and frequently into a forest, depending upon the local physical environment. E.P. Odum was so influenced that he informed his father's thinking about the systematic changes in human systems presented in American Regionalism (Odum \& Moore, 1938). E.P. Odum said that Shelford:

instilled ... four concepts [in him] that influenced his thinking thereafter: nature tends towards stability, 'the whole is more than the sum of its individual parts,' ecology is the study of large-scale systems and the interrelationships therein, and real ecology is not reductionistic (Craige, 2001, p. 25).

While completing his doctoral work at Yale University, H.T. Odum studied with G. Evelyn Hutchinson, one of the preeminent animal ecologists of the last century, who focused on population ecology and energy flow in systems (Hutchinson, 1978). The Odum brothers frequently exchanged ideas throughout their lifetime, and H.T. Odum specifically encouraged his older brother to consider new ideas, such as Hutchinson's holistic approach to the study of systems. Hutchinson influenced E.P. and H.T. Odum to focus on higher levels of organization, such as ecosystems, as the central unit of study, and E.P. Odum used this idea as one of the foundations for his ideas in the Fundamentals of Ecology (Craige, 2001).

Just as their father before them, the younger Odums were known to push their scholarly contemporaries to think in terms of large-scale systems. The following quotation summarizes E.P. Odum's view of holism as it relates to science:

It is self-evident that science should not only be reductionist in a sense of seeking to understand phenomena by detailed study of smaller and smaller components, but also synthetic and holistic in the sense of seeking to understand the large components as functional wholes. A human being, for example, is not only a hierarchical system composed of organs, cells, enzyme systems, and genes as subsystems, but it is also a component of supra-individual hierarchical systems such as populations, cultural systems, and ecosystems. Science and technology during the past half century have been so preoccupied with reductionism that the supra-individual systems have suffered benign neglect (1977, p. 1291).

The Odum brothers' concern for both human and natural systems is remarkable among biologists and naturalists of their generation. Scientific training in the 
mid- $20^{\text {th }}$ century often focused on natural subsystems; those who received this training historically have been reductionists and neglected the discussion of multiple and nested systems, including human systems (Odum, 1977). As a result, much of the recent work in the natural sciences defines problems but fails to bridge to pragmatic recommendations to ensure the future of human civilization. Prescriptions for the future were found in the work of both brothers as well as their father's work before them. Both generations made significant contributions to systems theory in their respective fields.

\section{European Roots of Ecology}

The Odums built upon the European tradition of ecology, drawing from the work of early theorists who developed critical concepts and groundbreaking research. Darwin's concepts of evolution and adaptation of an organism within an environmental context are at the root of early theory development. Ernst Haeckel, who avidly studied Darwin, coined the term ecology and was the first to use it in 1866 to "draw attention to the inclusive study of organisms in the environment, in contradistinction to the narrower study of organisms in the laboratory" (Keller \& Golley, 2000, p. 9). Haeckel discussed ecological adaptation, using the concepts of reciprocity and mutuality between organism and environment (Greif \& Lynch, 1983). By 1885, the term ecology was used in a book title, and the development of ecological theory rapidly progressed (Keller \& Golley, 2000, p. 9). Coursework began to be developed, and the first professional society, the British Ecological Society, was inaugurated in 1913. By 1935, botanist Sir Arthur Tansley challenged the use of ecological language in his article, "The Use and Abuse of Vegetational Concepts and Terms” (Keller \& Golley, 2000; Tansley, 1935). “Tansley challenged the term biotic community, because it aggregated animals and plants as members of a community without specifying their interrelationships and implicitly separated them from their physical environment" (Craige, 2001, p. 25). The problem with separating humans from the physical environment, Tansley asserted, is that one must then ask, "Is man a part of nature or not?" (Craige, 2001, p. 6). In his article, Tansley describes ecosystems as follows: "They form one whole category of the multitudinous physical systems of the universe, which range from the universe as a whole down to the atom" (Craige, 2001; Tansley, 1935, p. 290). Beginning from the whole-system perspective and the development of the concept of the ecosystem, Eugene and H.T. Odum built an ecological legacy in American scholarship.

\section{Social Work: Carel Germain \& Other Theorists}

Ecologically grounded practice dates back more than 100 years, with the practice of Jane Addams and Mary Richmond (Deegan, 1988; Richmond, 1917). However, in 1973, Carel Germain was the first social worker to formally apply ecological concepts to social casework, emphasizing the concept of ecosystem (Germain, 1973; Germain \& Gitterman, 1995; Robbins et al., 1998). She wrote about ecology and its conceptual relationship to social work:

Ecology is the science concerned with the adaptive fit of organisms and their environments and with the means by which they achieve a dynamic equilibrium and mutuality. It seems to furnish an appro- 
priate metaphor for a helping profession concerned with the relationships between human beings and their interpersonal and organizational environments, with helping to modify or to enhance the quality of transactions between people and their environments, and with seeking to promote environments that support human wellbeing (1973, p. 326).

Although Germain discusses ideas central to ecosystem ecology, she fails to cite previous use of the concept ecosystem, which, by that time, was widely recognized in the natural sciences, as introduced into contemporary American ecology by the Odum brothers (Craige, 2001; Hagen, 1992). However, Germain cites a range of contributors from the social sciences, including psychologists and social workers, specifically those professionals working in psychiatric settings.

Germain followed her general work about ecosystems ecology with a discussion of specific ecological concepts, such as time (1976) and space (1978), as they relate to the human condition. From ecological theory, Germain began development of the life model of practice (Germain \& Gitterman, 1995), which, she states, "may provide us with the necessary action concepts as guides in engaging the progressive forces and adaptive potentialities of the person, mobilizing the environmental processes as helping media, and altering elements of the environment" (Germain, 1973, p. 326). Germain points out that the central strength of the ecological perspective is its treatment of the individual and the problem, both in and as part of the environment, instead of focusing solely on the person or the illness as the problem. This point targets the age-old professional struggle between community systems practice and the medical model, which focuses solely on person and illness, removing him or her from the environmental context (Weick, 1981). In contrast to massive institutionalization based on assumptions of individual path-ology, ecological theory, by its very nature, requires study of the personenvironment interrelationship as a central theme for practice activities. In this initial discussion of the ecological life model, Germain focuses on previous use of ecological ideas by psychological theorists, including the concepts of adaptation and milieu.

Germain builds upon her early ecological work with a more specific conceptual treatment in Time: An Ecological Variable in Social Work Practice (1976), in which she discusses time as it relates to the rhythms of life from the biological, cultural, and social perspectives. Practice implications included casework planning surrounding the sense of time for children and elders as it relates to their respective developmental cycles. She points out that lengthy foster care placement decisions are out of sync with children's developmentally anchored experiences of time. On the other end of the lifespan, she points out that elders often have a fleeting sense of time, which also requires immediate case management action, according to this internal clock.

Germain continued to explore ecological concepts in her 1978 article, "Space: An Ecological Variable in Social Work Practice." She begins her discussion by noting that, "human beings have tended to overlook the physical settings in which they are embedded as sources of influence in behavior" (p. 515). In her discussion of human behavior in the physical environment, she states that there are "recip- 
rocal relations between the social and physical environments and their interaction with culture, personality, and behavior" (p. 516). The ecological concepts of population density and territoriality emerge in this discussion. She defines the latter term as:

an observable social phenomenon among individuals, groups, and families. People have feelings of possessiveness toward space and objects. They mark spatial territories with nameplates, signs, doors, locks, and fences. They use gestures, in-group jargon, and threatening verbal behavior to defend their control of space (p. 522).

This idea of territoriality has important implications for social work practice, given the human behavior realities associated with the individual's need for personal space as he or she interacts with others and the physical environment. For example, historical overcrowding of people in inner-city public housing has set a context for multiple social problems, including youth delinquency and gang violence.

Germain's commitment to the emerging social work ecological paradigm in the mid-1970s culminated in the edited collection Social Work Practice: People and Environments: An Ecological Perspective (1979b). Chapters include discussion on child welfare, social networks, and hospitalization within the ecological framework. The introductory chapter defines such foundational ecological concepts as adaptation, environment, stress and coping, competence, relatedness, and autonomy (Germain, 1979a). This book marks the first comprehensive overview of the ecological model as it relates to practice focusing on specific populations and problems.

Throughout her career, Germain continued to build upon the ecological framework, setting forth the groundwork for its emergence as a dominant social work perspective (Payne, 1997). Her collaborative work with Gitterman resulted in numerous publications, including the 1980 book The Life Model of Social Work Practice (Germain \& Gitterman, 1980), which was revised and presented in a new edition in 1996 after Germain's death (Germain \& Gitterman, 1996). In this second edition, a long overdue reference to Eugene Odum's work was made in the discussion of the concepts habitat and niche, metaphorically described by Odum as an organism's "address" and "profession," respectively (Germain \& Gitterman, 1996, p. 20). These concepts are defined respectively by Gitterman as a "place where the organism is found ... all the social settings of human individuals or groups" and "the social status occupied in a human community by an individual or a group" (Germain \& Gitterman, 1996, p. 23).

Germain developed social work ecological theory, while other social work theorists made equally important contributions to our understanding of holism and general systems theory (Bertalanffy, 1968) from a social environment perspective. Ralph Anderson and Irl Carter (1974) published Human Behavior in the Social Environment (HBSE), which, for two decades, was one of the most widely adopted texts for social work education on the subject of social systems (Robbins et al., 1998). Their discussion focuses on the concept of holon, defining the term as "denoting that a system is both a part of a larger suprasystem and it is itself a 
suprasystem to other systems" (Anderson \& Carter, 1984, p. 321). Their discussion draws on the natural science concepts of energy, synergy, entropy, and organization as they are related to systems at all levels. Anderson and Carter begin by discussing culture and society and move on to communities, groups, and organizations, and finally summarize the concepts as they relate to families and individuals (Anderson \& Carter, 1984). Their discussion, starting at the broadest of scales, is in contrast to other more recent HBSE texts, which focus more on the individual's development within the social environment (Hutchinson, 1999). In this text, Anderson and Carter draw upon the ecological approach, which they state, originated "probably" at the University of Chicago; however, references to specific theorists are absent, except for their 1990 reference to Kurt Lewin's field theory in which he develops the ecological psychology model (Anderson \& Carter, 1990). Anderson and Carter state that the ecological approach is "virtually synonymous with a systems approach" (1990, p. 262) but do not directly cite Germain or any other ecological systems theorists, including the Odum family. They do state that the term ecological systems is "used by some writers in the broad sense of systems that are hierarchically related. In biology and ecology, the term refers to living organisms in the earth's biosphere that are hierarchically related" (Anderson \& Carter, 1984, p. 230). Anderson and Carter's contributions to understanding human behavior in the social environment have endured over time, and their framework is based on nested systems, a hallmark concept of ecology.

Germain began to theorize about ecological social work practice 19 years after the death of H.W. Odum (Germain, 1973). In her early work, Germain reviews previous approaches that consider the environment from the psychological perspective, but she does not cite the work of the important, ecologically-focused sociologists before her, including scholars at the Chicago School of Sociology who were historically recognized for social ecology theory (McKenzie, 1925; Odum, 1951). Even though Germain was a scholar of social work history (Germain \& Hartman, 1980), she never recognized the senior Odum and only briefly mentions E.P. Odum in 1996 (Germain, 1973, 1976, 1978, 1979a; Germain \& Gitterman, 1996). Several factors may have contributed to less attention to Odum's work in the major schools of social work in the Northeast and Midwest: 1) Odum was recognized nationally primarily as a Southern regionalist and as the founding editor of Social Forces, 2) major scholarly work in social work research and treatment was being carried out in urban environments in the Northeast and in Chicago, where their major focus was on urban problems and urban approaches to practice and research, 3) because the most prominent schools of social work at the time did not study rural problems and approaches. In contrast to this focus of Northern schools, Odum's work focused on description and measurement of social problems with a broad prescription for policies and administrative practice. Germain also overlooked American natural systems ecologists and their European predecessors, including Haeckel and Tansley, who built substantial scientific theory by this time (Golley, 1993; Greif \& Lynch, 1983; Keller \& Golley, 2000).

THEORY BRIDGING BETWEEN SOCIOLOGY, ECOLOGY, AND SOCIAL WORK

The fields of sociology, ecology, and social work have benefited from the work of both generations of Odums. The Odums' theoretical contributions connect the 


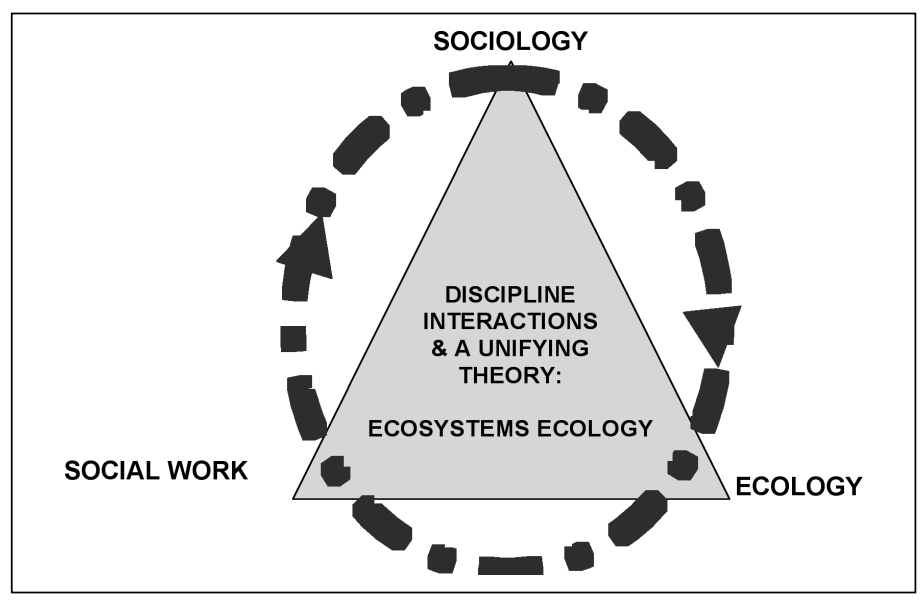

Figure 1. Theory Bridging Between Sociology, Ecology, and Social Work.

disciplines through ecosystems' ecology as a unifying and overarching paradigm (Odum, 1997). The inter-relationship of these three disciplines and the unifying paradigm in illustrated in Figure 1.

Ecology is a powerful perspective that bridges the gap, which has traditionally existed between natural and social sciences. Currently, social work incorporates basic human ecology. The Odum contributions offer social work an opportunity to construct interventions more broadly, incorporating a natural resource management strategy.

The theoretical cross-fertilization is best illustrated by the parallel concepts developed by both generations. The senior Odum began to integrate natural science and ecological concepts into his publications in the late 1930s (Odum, 1939; Odum \& Moore, 1938). In American Regionalism (1938), he devoted an entire chapter, "Exploring the Region: The Ecologists," (p. 323) to an exploration of the fundamental concepts of the natural sciences. In his descriptions of the concepts of biome and succession, Odum directly quotes his son Eugene:

The ecologist, according to Eugene P. Odum, characterizes his major divisions as "biotic formations" or "biomes," regions in which there is a uniform "climax," which is the highest type of vegetation possible in the region, and also in which the most important animals are similar. This idea of climaxes is fundamental in modern ecology, and it is believed that they represent climatic influences perhaps more than soil. Another fundamental idea is succession, which represents, of course, the environmental and time quality. Thus, if one lets a field in the southeastern deciduous forest lie fallow, there are, first of all, grasses of various kinds, then pines, and finally if we wait long enough, the oak-hickory deciduous or hardwood forest, which is the climax for that area. The animals will also change with the plants (p. 326). 
This passage not only marks a clear intersection of perspective in regionalism and modern ecology, but it also indicates the cross-fertilization of ideas within the Odum family, including feedback from the younger generation, specifically Eugene, to the senior Odum scholar. Today, ecologists and regionalists recognize this relationship as indicated by Kirby's observation that "Howard W. Odum and his Regionalist colleagues at the University of North Carolina are entangled in the roots of our Age of Ecology" (1991, p. 23; Hagen, 1992). Odum's holistic worldview, which was clearly passed onto his sons, is one of the earliest examples of ecological theory developed by a social work scholar. He was a man ahead of his time, laying out major ecological concepts for his regionalism theory development and research.

\section{STRENGTHS AND WEAKNESS OF ECOLOGICAL PERSPECTIVE IN SOCIAL WORK}

In social work and other social sciences, ecological theory has been applied to nearly every population and significant social problem, from juvenile delinquency (Fraser, 2004), to child development (Bronfenbrenner, 1979), and child abuse (Garbarino, 1977). However, ecological theory has been criticized as being inadequate (Finn \& Jacobson, 2003) and too abstract and impractical for the applied practice nature of social work (Wakefield, 1996). As a result, some scholars consider it to be only a perspective that "offers a lens" (Grief \& Lynch, 1983, p. 53) from which to view problems and practice rather than an appropriate theory related to intervention (Fraser, 2004). One of the reasons for this diversity of opinion may be because ecology and general systems are typically treated as synonymous; they are not. Ecology is an organic theory, whereas general systems theory is mechanistic, making it more difficult to apply to human social problems.

Ecological theory offers social work a paradigm that recognizes the interconnected nature of our world and the long-term survival of humans and other species and demands that we view ourselves and our environment in a holistic manner. Polluted air, which is the result of automobile and industrial emissions, has contributed significantly to the decrease of ozone and ultimately to the destruction of artic environments. As a result of Global Warming, the ice caps melt and populations living at or below sea level are losing their life-supporting land at alarming rates. The resulting human costs include the destruction of villages, towns, and cities throughout the world, from Charleston, South Carolina to Bangladesh. With growing environmental devastation, social work still needs to become more aggressive about using ecological theory above and beyond social ecology. This adaptation will require modification of theory and concepts to direct greater focus onto human issues in both the natural and social environments, as well as develop an ecological vocabulary and implement interventions grounded in applied ecology. In the face of globalization and rapid social and economic change, social work researchers and practitioners need advanced ecological theory to develop models of practice and research, incorporating sustainable development principles (Gamble \& Hoff, 2005).

These interconnected human/environmental phenomena have an impact on social work practice on a daily basis. However, as a profession, social work has failed to partner in the development of policy and practice to prevent environ- 
mental devastation and inherent human costs. This failure is most likely related to the fact that social work education has not yet embraced biological sciences, such as agriculture, geography, and environmental engineering. However, solving these human problems relies on an integrated natural and social science approach that would further expand our definition of generalist practice.

Another critique of ecological theory is that some of the major concepts, such as homeostasis and system stability, may be used to promote ideas of social systems remaining the same or constant rather than changing, which is a serious concern when dealing with issues of power and inequality of women, the poor, and people of color. Stability may be used as an excuse for oppressive systems and maintaining the dominant paradigm. Such concerns are well justified, given the history of social Darwinism and the fact that the idea of survival of the fittest has been misused as a justification for social stratification. However, when applied correctly, the ecological perspective provides a powerful framework for understanding systems and social issues, such as inequality and diversity. For example, ecological theory can be applied to the Civil Rights movement, which began as early as the 1940s (Odum, 1997) as a current that reached a critical mass by the 1954 Brown $v$. Board of Education decision and the massive socio-political changes that took place in subsequent decades. The momentum of the movement demanded that the oppressive and racist social stratification system had to change in the South, as H.W. Odum himself argued. Change was slow, but change did occur and continues to evolve. Among other human phenomena, ecological theory provides social work with a framework by which to study, track, and forecast social movements and social change.

\section{CONCLUSION}

Other disciplines have clearly recognized the connection between the two Odum generations and ecological theory development. However, the relationship between H.W. Odum and his sons has not been recognized in social work. In fact, with the exception of one author's brief reference (Siporin, 1980), the earliest social work discourse failed to even merely cite E.P. Odum (Germain, 1973, 1979a,b), even though he was an important and seminal ecology author.

This oversight is the result of at least three dynamics. First, H.W. Odum is overlooked in social work history, as he is traditionally remembered as a sociologist. Second, overall, our knowledge of natural science ecology is shallow and, thus, the historical roots of the science are overlooked. A third dynamic is that we have traditionally focused on social systems while failing to fully embrace the reality that natural environments, that is, the healthy forests, rivers, and clean water, air, and pollution, not only impact human behavior and welfare but must be intervention targets.

For the long-term welfare of human populations, social workers must more fully embrace ecosystems ecology. This requires enhancing our knowledge and improving our ecological theory. Then, the practice will be better informed, including progress in sustainable development. 

${ }^{1}$ In order to avoid confusing the reader, Howard W. Odum from here forth is referred to as H.W. Odum,
Eugene P. Odum, is referred to as E.P. Odum, and Howard T. Odum is referred to as H.T. Odum.

\section{References}

Anderson, R.E., \& Carter, I.E. (1974). Human behavior in the social environment: A social systems approach. New York: Aldine de Gruyter.

Anderson, R.E., \& Carter, I.E. (1984). Human behavior in the social environment: A social systems approach ( $3^{\text {rd }}$ ed.). New York: Aldine de Gruyter.

Anderson, R.E., \& Carter, I.E. (1990). Human behavior in the social environment: A social systems approach ( $4^{\text {th }}$ ed.). New York: Aldine de Gruyter.

Bertalanffy, L.V. (1968). General system theory: Foundations, development, applications (Rev. ed.). New York: George Braziller.

Brazil, W.D. (1988). Howard W. Odum, the building years, 1884-1930. New York: Garland.

Bronfenbrenner, U. (1979). The ecology of human development: Experiments by nature and design. Cambridge: Harvard University Press.

Brown, M.T. (2003). Howard T. Odum (1924-2002) awarded honorary doctorate of science. Retrieved December 10, 2003, from Engineering News at the University of Florida [electronic bulletin board] http://www.eng.ufl.edu/home/pubs/news/2003/odum.html

Carpenter, J.R. (1962). An ecological glossary (Rev. ed.). New York: Hafner Publishing

Craige, B.J. (2001). Eugene Odum: Ecologist and environmentalist. Athens: University of Georgia Press.

Deegan, M.J. (1988). Jane Addams and the men of the Chicago School, 1892-1918. New Brunswick, NJ: Transaction Books.

Feldman, R.A., \& Kamerman, S.B. (Eds.). (2001). The Columbia University School of Social Work: A centennial celebration. New York: Columbia University Press.

Finn, J.L., \& Jacobson, M. (2003). Just practice: Steps toward a new social work paradigm. Journal of Social Work Education, 39(1): 57-78.

Fraser, M.W. (Ed.). (2004). Risk and resilience in childhood: An ecological perspective ( $2^{\text {nd }}$ ed.). Washington, D.C.: NASW Press.

Gamble, D.N., \& Hoff, M.D. (2005). Sustainable community development. In M.O. Weil (Ed.), The handbook of community practice (pp. 169-188). Thousand Oaks, CA: Sage.

Garbarino, J. (1977). The human ecology of child maltreatment. Journal of Marriage and the Family, 39, 721-735.

Germain, C.B. (1973). An ecological perspective in casework practice. Social Casework, 51(June): 323-330.

Germain, C.B. (1979a) (Ed.). Introduction: Ecology and social work. In Social work practice: People and environments, New York: Columbia University Press.

Germain, C.B. (Ed.). (1979b). Social work practice: People and environments. New York: Columbia University Press.

Germain, C.B. (1991). Human behavior in the social environment: An ecological view. New York: Columbia University Press.

Germain, C.B., \& Gitterman, A. (1980). The life model of social work practice. New York: Columbia University Press.

Germain, C.B., \& Gitterman, A. (1995). Ecological perspective. In R.L. Edwards (Ed.), Encyclopedia of Social Work (19 ${ }^{\text {th }}$ ed., pp. 816-823). Washington, D.C.: NASW Press.

Germain, C.B., \& Gitterman, A. (1996). The life model of social work practice: Advances in theory and practice $\left(2^{\text {nd }}\right.$ ed.). New York: Columbia University Press. 
Germain, C.B., \& Hartman, A. (1980). People and ideas in the history of social work practice. Social Casework, 61(June): 323-331.

Golley, F.B. (1993). A history of the ecosystem concept in ecology. New Haven, CT: Yale University Press.

Greif, G.L., \& Lynch, A.A. (1983). The eco-systems perspective. In C.H. Meyer (Ed.), Clinical social work in the eco-systems perspective (pp. 35-74). New York: Columbia University Press.

Hagen, J.B. (1992). An entangled bank: The origins of ecosystem ecology. New Brunswick, NJ: Rutgers University Press.

Hall, C.A.S. (1995). Maximum power: The ideas and applications of H.T. Odum. Niwot: University of Colorado Press.

Howard W. Odum, sociologist, dies. (1954, November 9). The New York Times, p. 27.

Hutchinson, E.D. (1999). Dimensions of human behavior: Person and environment. Thousand Oaks, CA: Pine Forge Press.

Hutchinson, G.E. (1978). An introduction to population ecology. New Haven, CT: Yale University Press.

Karls, J.M., \& Wandrei, K.E. (Eds.). (1994). Person-in-environment system: The PIE classification system for functioning problems. Washington, D.C.: NASW Press.

Keller, D.R., \& Golley, FB. (Eds.). (2000). The philosophy of ecology: From science to synthesis. Athens: University of Georgia Press.

Kirby, J.T. (1991). The Chapel Hill regionalists and the Southern landscape. In V.G. Ledra \& T. Westendorp (Eds.), The United States South: Regionalism and identity (pp. 167-185). Rome: Bulzoni Editore.

McDonough, J.A. (1993). Men and women of goodwill: A history of the Commission on Interracial Cooperation. Unpublished doctoral dissertation, University of Virginia, Charlottesville.

McKenzie, R.D. (1925). The ecological approach to the human community. In R.E. Park, E.W. Burgess \& R.D. McKenzie (Eds.), The city (pp. 63-79). Chicago: University of Chicago Press.

Meyer, C.H. (Ed.). (1983). Clinical social work in the eco-systems perspective. New York: Columbia University Press.

Milligan, M.J. (1994). The contradictions of public service: A study of Howard Odum's intellectual odyssey. Unpublished doctoral dissertation, University of Virginia, Charlottesville.

Odum, E.P. (1953). Fundamentals of ecology. Philadelphia: Saunders.

Odum, E.P. (1977). The emergence of a new integrative discipline. Science, 195: 1289-1293.

Odum, E.P. (1983). Basic ecology. Philadelphia: Saunders.

Odum, E.P. (1997). Ecology: A bridge between science and society. Sunderland, MA: Sinauer.

Odum, E.P. (1998). Ecological vignettes: Ecological approaches to dealing with human predicaments. Amsterdam: Harwood.

Odum, E.P. (2004). Landscape ecology of the future: A regional interface of ecology and socioeconomics. In J. Liu \& W.W. Taylor (Eds.), Integrating landscape ecology into natural resource management (pp. 461465). Cambridge: Cambridge University Press.

Odum, H.T. (1971). Environment, power, and society. New York: Wiley-Interscience.

Odum, H.T. (1983). Systems ecology: An introduction. New York: Wiley-Interscience.

Odum, H.T. (1994). Ecological and general systems (Rev. ed.). Niwot: University of Colorado Press.

Odum, H.T., \& Odum, E.C. (2001). A prosperous way down. Boulder: University of Colorado Press.

Odum, H.W. (1909). Religious folk songs of Southern Negros. American Journal of Religious Psychology and Education, 3(July), 265-365.

Odum, H.W. (1910). Social and mental traits of the Negro: Research into the conditions of the Negro race in Southern towns. New York: Columbia University Press.

Odum, H.W. (1920). School of Public Welfare. Odum papers of the Southern History Collection, University of North Carolina.

Odum, H.W. (1922). The journal's program. Social Forces, 1(1): 56-61 
Odum, H.W. (1923a). Democracy in relation to government, industry, community, and the Ku Klux Klan. Social Forces, 1(3): 315-320.

Odum, H.W. (1923b). Effective democracy. Social Forces, 1(2): 178-183.

Odum, H.W. (1923c). Newer ideals of public welfare. The Annals of the American Academy of Political and Social Sciences, 105: 1-6.

Odum, H.W. (1923d). Social work in relation to democracy and progress. Social Forces, 1(4): 471-476.

Odum, H.W. (1926). An approach to social welfare. Chapel Hill: University of North Carolina.

Odum, H.W. (1931, December 30). Lynchings, fears, and folkways. The Nation, 133, 719-720.

Odum, H.W. (Ed.). (1932). Civilization and society: An account of the development and behavior of human society. New York: Holt.

Odum, H.W. (1934). The case for regional-national social planning. Social Forces, 13(1): 320-327.

Odum, H.W. (1936). Southern regions of the United States. Chapel Hill: University of North Carolina Press.

Odum, H.W. (1939). American social problems: An introduction to the study of the people and their dilemmas. New York: Holt

Odum, H.W. (1945). American social problems: An introduction to the study of the people and their dilemmas (Rev. ed.). New York: Holt.

Odum, H.W. (1947a). The way of the South. New York: Macmillan.

Odum, H.W. (1947b). Understanding society: The principles of dynamic sociology. New York: Macmillan.

Odum, H.W. (1951). American sociology: The story of sociology in the United States to 1950. New York: Longmans, Green.

Odum, H.W. (1997). Race and rumors of race: The American South in the early forties. Reprint, with a forward by Bryant Simon. 1943. Baltimore: Johns Hopkins University Press.

Odum, H.W., \& Moore, H.E. (1938). American regionalism. New York: Holt.

Odum, H.W., \& Willard, D.W. (1925). Systems of public welfare. Chapel Hill: University of North Carolina Press.

Payne, M. (1997). Modern social work theory ( $2^{\text {nd }}$ ed.). Chicago: Lyceum.

Richmond, M.E. (1917). Social diagnosis. New York: Russell Sage.

Robbins, S.P., Chatterjee, P., \& Canda, E.R. (1998). Contemporary human behavior theory: A critical perspective for social work. Needham Heights, MA: Allyn \& Bacon.

Rotabi, K.S. (2004). Theory bridging between sociology, ecology, and social work: The intellectual legacy of the Odum family. Unpublished doctoral dissertation, University of North Carolina, Chapel Hill.

Sanders, L.M. (2003). Howard W. Odum's folklore odyssey: Transformation to tolerance through African American folk studies. University of Georgia Press: Athens, GA.

Siporin, M. (1980). Ecological systems theory in social work. Journal of Sociology and Social Welfare, VII (4), 507-532.

Smith, K.M. (2001). The legacy of the school's founder, Howard W. Odum. Contact: A Newsletter for the [University of North Carolina] School of Social Work Alumni and Friends, 18(Spring): 4.

Sosna, M. (1977). Southern liberals and the race issue: In search of the silent South. New York: Columbia University Press.

Tansley, A.G. (1935). The use and abuse of vegetational terms and concepts. Ecology, 16: 284-307.

Wakefield, J. (1996a). Does social work need an ecosystems perspective? Part 1 . Is the perspective clinically useful? Social Service Review, 70(1): 1-32.

Weick, A. (1981). Reframing the person-in-environment perspective. Social Work, 26: 140-143. 
Author's Note:

Address correspondence to: Karen Smith Rotabi, Ph.D., LMSW, MPH, assistant professor of Social Work, Virginia Commonwealth University, 1001 W. Franklin St., P.O. Box 842027, Richmond, VA 23284-2027, USA. e-mail: ksrotabi@vcu.edu. 